\title{
Comparative Advantage and Antitrust Law
}

\author{
Frank H. Easterbrook $\uparrow$
}

Antitrust law has become a branch of industrial organization, itself a branch of economics. Professor Areeda's Article illustrates the point. ${ }^{1}$ At every turn he searches for the economic arguments pro and con. $\mathrm{He}$ does this so well that I have little to add. Instead I raise an issue that is old in thinking about economic arrangements but novel in thinking about the application of law to industrial organization: comparative advantage.

Until the 1970's antitrust law sorted all business practices into two bins. The practices in one bin were declared unlawful per se; the practices in the other were evaluated under the rule of reason, which as a practical matter meant that they were declared lawful per se, although the attorneys' fees incurred on the way to the ritual absolution were a hefty tax on the lawful conduct. The per se rules came under attack on the ground that many of the condemned practices might be beneficial, making summary condemnation improvident. Throughout the last fifteen years courts have been willing to indulge explanations for conduct formerly condemned. Along the way the rule of reason also became a testing ground for explanations, so that three years ago the Supreme Court finally declared an important business arrangement illegal under the rule of reason. ${ }^{2}$ At the same time the Court adopted a middle ground, a "quick look" version of the rule of reason under which justifications for business practices might be summarily evaluated. ${ }^{3}$ Modern antitrust law is a search for economic explanations of problematic conduct. If the explanations show the conduct efficient-and therefore ultimately to the consumers' benefit-then the court stays its hand; if not, the court condemns the conduct. Professor Areeda's essay, like his treatise, both praises the new approach to antitrust and offers thoughtful assessments of the justifications that could be offered for each business practice.

The dominant approach puts us at risk of losing sight of the impetus

$\dagger$ Judge, United States Court of Appeals for the Seventh Circuit; Senior Lecturer, The Law School, University of Chicago. B.A. 1970, Swarthmore College; J.D. 1973, University of Chicago.

1. Areeda, Monopolization, Mergers, and Markets: $A$ Century Past and the Future, 75 CALif. L. REV. 959 (1987).

2. NCAA v. Board of Regents, 468 U.S. 85 (1984).

3. Id. at 110 \& n.42; see also National Soc'y of Professional Eng'rs v. United States, 435 U.S. 679 (1978). 
for per se rules: a belief that courts are not very good at divining the reasons for and effects of complex business practices. In corporate law the "business judgment rule" insulates most decisions from judicial review because there is little likelihood that systematic judicial intervention would make investors better off. Judges' decrees would increase the riskiness of business decisions without making decisions better. After all, judges are not selected for business acumen and are not penalized for bad decisions. We praise managers who hold the stock of the firms they manage, because this aligns managers' interests with investors' interests; managers and investors do well or poorly together. Self-interest is a powerful spur. If a judge should bet on the astuteness of his business judgments by holding stock in the firms that appeared before him, we would hustle the judge off to jail. An essential ingredient of imterest alignment in the business world is an impermissible lack of disinterest in the judicial world. So we do not trust judges to make business decisions in corporate law. Yet antitrust law now calls for the same sorts of economic judgments. We ought to be skeptical of judges' and juries' ability to give good answers. ${ }^{4}$

There is a large difference between corporate and antitrust law. Managers' mistakes generally harm only people who have elected to affiliate with the firms as investors, suppliers, or employees. Managers who injure stockholders can expect to find their salaries falling or to be given walking papers. Blunders induce automatic penalties, to which legal processes could add little. The "market"-to personify a set of interactions that involve real people protectimg their own interests-is the principal safeguard of investors. Managers who monopolize injure customers, who cannot retaliate readily. There are no automatic penalties. These effects on third parties justify a greater judicial role.

In deciding how much greater the role, however, we must inquire into comparative advantage. Comparative advantage in economics means an advantage relative to the cost of the next best alternative. I know a lot about computers, so I can repair my own; I may be able to repair the machine in less time than it takes my neighborhood computer shop to do so. Nonetheless, when my machine breaks I will turn it over to the shop because the shop has a comparative advantage. If I were to fix the computer, I would have to stop working on opinions and articles; the cost of fixing the machine myself is the loss of whatever else I could accomplish during the time. The value of the hours I would surrender may well be greater than the value (in alternative uses) of the time it

4. For three essays that elaborate some of the ideas presented here, see Easterbrook, The Limits of Antitrust, 63 TEX. L. REV. 1 (1984); Easterbrook, Workable Antitrust Policy, 84 Mich. L. REv. 1696 (1986); Easterbrook, On Identifying Exc/usionary Conduct, 63 NoTRE DAME L. REV. 972 (1986). 
takes the computer shop to fix my machine, even if the shop takes more time than I would. So the shop has a comparative advantage over me in fixing computers.

Judges also may be able to fix markets when they are monopolized. Yet other social institutions may have a comparative advantage over courts. The principal competing institution is the actions of business rivals. If there are monopoly profits to be inade, rivals enter the market (or expand their production) and undercut the monopolist. No one doubts that this occurs. The question is, "How long does it take?" Competition is the long-run solution to inonopoly. Perhaps antitrust law speeds up the arrival of the long run. Perhaps it does not. Unless we know it does, judges ought to apply their talents in other fields, where they have a comparative advantage over other institutions.

Expressing the extent of the law's comparative advantage over rivalry in undercutting monopoly requires the use of the social scientist's terms "false positive" and "false negative." If a judge wrongly condemns as monopolistic a busmess practice that is efficient and beneficial to consumers, that is a false positive. Consuners would be better off if the judge had decided the case the other way. If the judge wrongly excuses conduct that is harmful to consumers, that is a false negative. Litigation produces both false positives and false negatives. The more complex or unusual the conduct, the more false positives and false negatives there will be. And of course the more complex the conduct, the longer the case will take to conclude, and the more it is apt to cost along the way. All the while competitors will be trying to undercut monopolists.

For the law to have a comparative advantage, legal processes must be able to beat market processes to a conclusion in assessing novel business practices. (Common practices may be governed by rules that deter similar conduct, and the duration of litigation is accordingly less important.) If rivals will undo a monopoly or evade a questionable practice before judges can decide the case, there is little point in incurring the costs of litigation and suffering the inevitable mistaken judgments. If the business practices in question may be long-lived, then courts nay have a comparative advantage wlien false positives are few and when false negatives will survive competitive pressure. Unless there is a strong reason to suspect that a monopoly or monopolistic practice can survive the attempts of other firms to undermine it, then the costs of inaction (excusing harmful conduct) are low. Unless there is strong reason to suspect that we can identify harmful conduct accurately, then the costs of action (condemning beneficial conduct) are high.

The conditions for useful legal intervention may be inet when we know a lot about the practice-for when we know but little the risk of error goes up, and the risk of false positives may be substantial. People 
are quick to condemn what they do not understand. Hasty or uninformed judgments may condemn novel practices just because of their novelty. Often it takes a decade or more to determine what a business practice really does. The law moves too fast for our own good, because courts act in advance of the explanation. Judges move slower than markets but faster than the economics profession, a deadly combination.

It may be prudent for a court to act on limited knowledge if a mistaken condemnation can be washed away as easily as the contrary error would be. Yet there is a bias in the error-correcting devices of the law. Mistakes of law are not subject to competitive pressures. If a judge errs in saying that the NCAA's contract with the TV networks for college football is a violation, there is no competitive way to undermine the decision, as there might be a competitive way to undermine the contract. Once the court speaks, the contract is gone. If the prohibition was mistaken, we shall suffer the consequences indefinitely. So, too, if the Supreme Court announces a rule such as the "filed rate doctrine," under which a cartel price is beyond challenge if reflected in tariffs filed with the ICC, or the rule of per se illegality for resale price maintenance, there are no automatic market pressures that test the wisdom of the rule. Quite the contrary. After some years have gone by, the Court is apt to declare the rule exempt from further scrutiny. ${ }^{5}$

Law has a comparative advantage over markets, then, when legal processes are rapid, when false positives are rare (or quickly corrected), and when markets are sluggish about correcting false negatives. These criteria are met for naked cartels (which may be condemned quickly and with great assurance that condemnation is appropriate) and for large mergers in markets with serious barriers to entry (the market power from which may take a long time to erode through competitive pressure). They are rarely met for novel business practices-those that courts are encountering for the first time. The rate of false positives may be particularly high because cases arrive in court ahead of explanations for the practices. It is easier to call practices "abuses" than to understand the real economic effects of novel arrangements. Courts can see the wounded plaintiffs but not the beneficiaries.

How does this approach tally with Professor Areeda's? He is suspicious of Aspen on the ground that the jury was given foggy instructions. ${ }^{6}$ I am suspicious on the ground that we-meaning judges, lawyers, economists, and other professions taken together-know very little about such joint selling arrangements. False positives are apt to be frequent, and it is difficult to undo mistaken condemnations. It is easy to see, however,

5. E.g., Square D Co. v. Niagara Frontier Tariff Bureau, Inc., 106 S. Ct. 1922 (1986) (holding the "filed rate doctrine" inviolate).

6. Areeda, supra note 1, at 963-65, 979-80. 
how a decision like $A$ spen could discourage businesses from entering into beneficial joint operations for fear that they would be exposed to antitrust liability if they should withdraw. ${ }^{7}$ It is also frightening to contemplate businesses using liability for competition as a justification for making or retaining monopolistic joint arrangements-as a form of "mandatory cartelization defense." And I join with a huzzah in Professor Areeda's caveat to Aspen that "[t]he monopolist's intent to keep as much of the market as he can for himself is not the kind of exclusionary intent that automatically converts ordinary and useful behavior into unlawful monopolization."

Indeed, Professor Areeda's fine essay largely consists in one warning after another about the dangers both of simplistic condemnation of novel practices-which he rightly says increases business risk to an unacceptable degree-and of employing highfalutin' theories that use a battery of equations to show how apparently beneficial practices, such as price competition, may be harmful. ${ }^{9}$ Antitrust law need not contain a bias, with per se rules working only in plaintiffs' favor. If practices that are harmful in eighty percent of the cases should be unlawful per se, then practices that are beneficial in eighty percent of the cases should be lawful per se. More discriminating analysis should be reserved for the rare intermediate case. The practice that is passed over by a rule of per se legality, the false negative, can be taken care of by business rivals. This is the sort of situation in which market forces have a comparative advantage over courts.

Yet I ain not entirely happy with Professor Areeda's presentation, because despite his warnings about simplicity and complexity alike, he does not always ask where the comparative advantage of courts runs out. Take his discussion of the Empire Gas case. Empire Gas stole business from rivals by lying to customers and selling below cost. Professor Areeda regards the conduct as an "attempted conspiracy" that might warrant sanctions without proof that Empire could obtain a monopoly. ${ }^{10}$ But another alternative is that the court misunderstood Empire's costs of

7. This fear explains the decision in Olympia Equip. Leasing Corp. v. Western Union Tel. Co., 797 F.2d 370 (7th Cir.), reh'g denied, 802 F.2d 217 (7th Cir. 1986), which read Aspen narrowly.

8. Areeda, supra note 1 , at 965 . This point was established in my court in Olympia. Not all voices speak as one on this point, however. Fishman v. Estate of Wirtz, 807 F.2d 520 (7th Cir. 1986) treats the "essential facilities doctrine" as the source of a requirement that monopolists act fairly toward people who might want to buy their product-even when there is no conceivable injury to consumers from the "unfair" conduct. $I d$. at 533-35, 539-42. It is not a position to be welcomed. See id. at 570-75 (Easterbrook, J., dissenting).

9. E.g., Areeda, supra note 1, at $972,973-75$. On the same subject, see my essays, supra note 4, and T. Brennan, Understanding "Raising Rivals' Costs" (U.S. Dep't of Justice, Antitrust Division, Economic Analysis Group Discussion Paper No. 86-16, Sept. 26, 1986) (copy on file with the author).

10. Areeda, supra note 1, at 975 n.76 (discussing United States v. Empire Gas Corp., 537 F.2d 296 (8th Cir. 1976), cert. denied, 429 U.S. 1122 (1977)). 
doing business, or confused an introductory discount with predatory conduct, or some such mistake. If we take it as a given that Empire could not obtain a monopoly, because entry into the business of retailing liquid natural gas is easy and rapid, then there are only two plausible explanations for Empire's conduct: It was beneficial to consumers (low prices are usually beneficial), or it was a mistake by Empire's managers that threw away the investors' money. If it was the former, then the law must not interfere; if it was the latter, then the law need not interfere, because mistakes are self-deterring. This is the lesson of the business judgment cases in corporate law. Managers who injure their firms face their private days of judgment.

Only by neglecting the comparative advantage of markets over law in some cases could Professor Areeda equate Empire Gas and American Airlines. ${ }^{11}$ In Empire Gas the defendant paid a penalty for failure in the market, while in American Airlines there was no penalty. A firm that proposes a cartel stands to gain but never to lose; a legal penalty is necessary to change the incentives. A firm that sells its product for too little money, as in Empire Gas, stands to lose but rarely to gain. This explains the Supreme Court's thoughtful opinion in the Matsushita case. ${ }^{12}$ Longterm sales below cost are self-deterring. This practice is no different from designing expensive products that no one buys-a court need not penalize the designers of the Edsel to stop them from wasting money, and a court need not penalize would-be monopolists who fail to achieve their objective.

The same principles should inform our approach to market power in antitrust cases. Professor Areeda questions whether a demonstration of market power should be required in every case. ${ }^{13}$ The Supreme Court has begun to add market power requirements even to categories of conduct once thought unlawful per se. ${ }^{14}$ Professor Areeda does not doubt the importance of market power in principle, though he would not require proof in the case of horizontal conspiracies. Three of the papers in this Symposium suggest that proof of market power may be more troublesome than useful. ${ }^{15}$ The argument runs: Given that we know a practice is harmful, and given the difficulty of proving market power in

11. See Areeda, supra note 1, at 974-75 (discussing United States v. American Airlines, Inc., 743 F.2d 1114 (5th Cir. 1984), cert. dismissed, 106 S. Ct. 420 (1985)).

12. Matsushita Elec. Indus. Corp. v. Zenith Radio Corp., 106 S. Ct. 1348, 1354-60 (1986).

13. Areeda, supra note 1, at 973.

14. See Jefferson Parish Hosp. Dist. No. 2 v. Hyde, 466 U.S. 2, 13-14 (1984).

15. See Turner, The Durability, Relevance, and Future of American Antitrust Policy, 75 CALIF. L. REv. 797, 801 (1987); Sullivan, The Viability of the Current Law on Horizontal Restraints, 75 CALIF. L. Rev. 835, 848-51 (1987); Kauper, The Sullivan Approach to Horizontal Restraints, 75 CAlif. L. Rev. 893, $905-08$ (1987). Professor Kauper qualifies his position substantially, supra at 914, and would allow any case to be dismissed if on a quick look it is clear that the defendants could not possess power. 
litigation, why not dispense with the proof? Yet why not turn around the question? Given that a practice indulged without market power is either beneficial to consumers or self-defeating to its practitioners, why use the courts to condemn the conduct? Perhaps people are mistaken in believing that the practice in question is harmful. If they are not mistaken, if the practice is indeed harmful, then firms without market power will lose business and desist soon enough. Unless courts are very good at separating beneficial from harmful practices, a process of condemning questionable practices pursued by firms without power will spin the wheels of the courts-at great expense-for no substantial result. Markets have a comparative advantage over courts in dealing with the conduct of firms that lack market power.

The risk of error cuts both ways. Just as courts may err in thinking that a practice is harmful, so they may err in thinking that a firm does not have market power. If they mistakenly dismiss cases on the ground of lack of power, they will inflict a loss on society. So, too, the costs of proving market power are a social loss, when there is in fact power. Yet power often is evident at a glance. In the Indiana Dentists case ${ }^{16}$ the fact that the defendants did a substantial portion of all dental work in southern Indiana was proof enough. Patients would not travel hundreds of miles or turn to barbers in order to escape a cartel of dentists. I do not think that antitrust law has been plagued by difficulty in establishing market power. Quite the contrary, there has been a bias in favor of finding power when there is none. So we have "markets" such as downhill skiing in Aspen, Colorado, or Saturday afternoon television in the fall, altliough these have no economic significance. ${ }^{17}$ The history of merger law in the Supreme Court is a history of finding market power in bizarrely defined "submarkets" that escaped the attention of mortal economists. The long-term bias in favor of finding too much market power reduces the costs of making market power an essential ingredient in every antitrust case.

It is time to quit. The overlap between Professor Areeda's essay and my own views is far too great to spend much time criticizing his work. To sum up: Professor Areeda says much with which I agree, and very little that is open to question. The questions all turn on matters of comparative advantage, and, having raised the issue, I shall leave the implications unexplored for now.

16. FTC v. Indiana Fed'n of Dentists, 106 S. Ct. 2009 (1986).

17. Professor Areeda compellingly critizes the "market" defined in Aspen. Areeda, supra note 1, at 979-80. On the "market" defined in NCAA v. Board of Regents, 468 U.S. 85 (1984), see both Justice White's dissent, id. at 120, and Hutchinson, Antitrust 1984: Five Decisions in Search of a Theorv. 1984 SUP. CT. REv. 69, 109-12 (1985). 
